\title{
A holistic experience in the integrated learning of specialized English and content in engineering degrees
}

\author{
Irina Argüielles Álvarez \\ irina@euitt.upm.es \\ Universidad Politécnica de Madrid, Spain
}

\begin{abstract}
This paper aims to outline a theory-based Content and Language Integrated Learning course and to establish the rationale for adopting a holistic approach to the teaching of languages in tertiary education. Our work focuses on the interdependence between Content and Language Integrated Learning (CLIL), and the use of Information and Communication Technologies (ICT), in particular regarding the learning of English within the framework of Telecommunications Engineering. The study first analyses the diverse components of the instructional approach and the extent to which this approach interrelates with technologies within the context of what we have defined as a holistic experience, since it also aims to develop a set of generic competences or transferable skills. Second, an example of a course project framed in this holistic approach is described in order to exemplify the specific actions suggested for learner autonomy and CLIL. The approach provides both an adequate framework as well as the conditions needed to carry out a lifelong learning experience within our context, a Spanish School of Engineering. In addition to specialized language and content, the approach integrates the learning of skills and capacities required by the new plans that have been established following the Bologna Declaration in 1999.
\end{abstract}

Key words: Content and Language Integrated Learning, Information and Communication Technologies, holistic approaches, tertiary education, skills and capacities.

\section{INTRODUCTION}

The changes introduced into the degrees affecting Engineering studies at the Universidad Politécnica de Madrid (UPM) led to the implementation four years ago of a new compulsory subject across all its Schools and Faculties: English for Professional and Academic Communication (EPAC). At the Escuela Universitaria de Ingenería Técnica de Telecomunicación (EUITT-UPM) this compulsory subject was scheduled for the seventh semester in the new four-year degrees. The University also established a B2 proficiency level in accordance with the Common European Framework of Reference for Languages (CEFRL) as the minimum level for students to enrol in the subject. In this context, EPAC was planned to respond to the needs at the EUITT, incorporating methodologies applied to previous pilot experiences which had resulted in 
very positive outcomes (Argüelles et al. 2011). Two of the most important research areas which initially supported the idea of an advanced course designed to offer engineering students an alternative to a traditional one were: Content and Language Integrated Learning and electronic material development, both of which could be used in either distance or blended learning modalities.

Although it is not our intention here to address the question of the most appropriate term to be applied in our setting, English-medium instruction, English-medium education or Integrated Content and Language in Higher Education could fit our conceptual framework, as has been the case in previous Content and Language Integrated Learning projects (Sercu 2004, Unterberger and Wilhelmer 2011). Content and Language Integrated Learning (CLIL) is used here instead of Content Based Instruction (CBI) as it highlights the fact that specific content is mainly used to provide a framework where the learning of both the content and the language are considered to be equally important. As in Dafouz and Guerrini (2009), this integration is understood from a communicative perspective in which the goal is the development of communicative abilities within a specific field or context. According to Fernández Fontecha (2001), integrated learning of curricular subjects and proficiency in a foreign language can be achieved through different methods. In our approach, CLIL fits the constructive model, where the initial hypothesis is that language is learnt when there is a real need for communication (Halliday 1975, 1978). Here, the actual learning departs from a motivational orientation related to the non-linguistic aspect of the subject, project or task; the learning style is highly associated with the task-based or the project-based approach, where students must use the foreign language to do the course assignments.

Whilst the feature of instrumental motivation, far beyond the basic integrative aspects of the language, is one of the most important factors in this framework, the success of the approach will depend on a careful selection, organization and integration of activities leading to relevant "true-to-life" outcomes. In the case of Telecommunications students, extra motivation derives from the unavoidable incorporation of Information and Communication Technologies (ICT) as a necessary tool to achieve the expected results. Hence, discrete activities are very often structured in more complex tasks (Ellis 2003, Skehan 1996) or even class projects, which allow related technologies to be included 
and adapt to the necessities and specific circumstances of the Centre, the group, the instructor or a group of students’ particular goals.

Nevertheless, parallel to the real-world tasks and projects, class activities also have beneficial effects on course renewal and update. The opportunity to develop Learning Objects (LO) from the final products derived from previous class activities cannot be overlooked. This fundamental data model implies the use of modular and self-content material, separately or as part of a lesson, module or course. Thus the main advantage of such material is its flexibility. It can easily be imported or exported from one platform to any other, utilized with different groups, courses and across subjects, degrees, Schools or Universities. Researchers such as del Moral and Cernea (2005) pointed to cooperation with students in the development of materials as a means to convey new knowledge (also cf. Argüelles Álvarez 2005, 2006). Electronic materials can subsequently be used both for autonomous learning as well as for more traditional “learning directed by others” (LDO) syllabus designs, including b-learning (blended learning), as long as they respect the basic teaching and learning best practices concerning the use of technologies. As a most effective medium of organizing and compiling completed tasks, technologies also favour the collection of potential class materials generated year after year as a result of the course experience. Once again, the storage of LO for easy localization implies a necessary collaboration with professionals from areas of ICT.

In what follows, we will outline a theory-based Content and Language Integrated Learning course based on the interdependence between CLIL and the use of ICT. We will focus on a project developed within the framework of Telecommunications Engineering which thoroughly integrates both the proposed holistic approach to the teaching of languages in tertiary education and the learning of skills and capacities required by the new plans established after the Bologna Declaration in 1999.

\section{DESIGNING THE COURSE}

In the case of the Escuela Universitaria de Ingenería Técnica de Telecomunicación, the EPAC course, as with many other subjects included in the new curriculum of this centre, has inherited or adapted contents and materials from the former three-year 
engineering degree. The last two subjects of a module which includes three elective subjects on professional communication were the point of departure for the design of the new six-ECTS compulsory subject. These subjects matched the contents agreed upon by the members of the Department of Applied Linguistics as compulsory and were hence taught across the different Faculties and Schools at the UPM. On the other hand, the general contents of these courses, such as writing a CV, a cover letter, an e-mail message or an abstract, and attending a job interview or giving a presentation on a specialized topic, are fairly typical and likely within different approaches, and are already being taught in every Centre at the UPM.

\section{II.1. Learning context}

Initially, the adaptation to the new degrees could have seemed an easy task to carry out. Yet two important factors constrained the design of the new subject. With the new entrance requirements, all new graduate students are now required to reach a B2 proficiency level of English, as described by the Common European Framework of Reference for Languages, before beginning the course. In contrast, students in the previous three-year degrees were mostly below the B1 level. Additionally, a new condition changed the status of the subject. Nowadays students are obliged to enrol and pass this subject, whereas in the past, it was just an elective subject in the Telecommunications curriculum.

It is difficult and definitely beyond the limits of this study to determine the learners' objectives for learning English, nevertheless, it might be predicted that the proficiency level and the compulsory nature of the subject affect the students' motivation. This prediction matches Schumann's view in second language learning contexts (1986: 383) that an integrative motivation seems to be more effective when the learning of the language is not a necessary condition. Therefore, in integratively-oriented contexts, the learner wants to learn the second language to meet with, talk to or find out about speakers of the target language. On the other hand, instrumentally-oriented learners want to learn the language for more utilitarian reasons, such as getting ahead in their career or dealing with English-speaking technical co-workers or clients. It has generally been thought that integrative motivation is the more powerful of the two, but a great 
deal of instrumental motivation is in fact needed on the part of the students who enrol in the new compulsory EPAC course.

The instrumental/integrative construct helps to analyse students' preferences or needs at the beginning of the course in order to prepare integrated content and language activities that raise their motivation. Defined in Gardner (1985), it includes three components: desire to achieve goals, effort devoted towards achieving such goals and satisfaction with the task. Given that many studies have found evidence that motivation correlates significantly with achievement in the second language (Gardner and McIntyre 1993: 3), motivation is considered crucial to the acquisition process.

\section{II.2. Theme-based and skill integrated instruction}

Content and Language Integrated Learning differs from more traditional language classes in that content is seen as driving the curriculum, but at the same time the approach provides good opportunities for students to practise across the skills areas as they work on higher-level language skills (e.g. by integrating reading and listening skills). From the range of prototypical models at university levels (theme-based language instruction, sheltered content instruction and adjunct language instruction), theme-based or topic-based models are probably the most widespread in tertiary educational settings in Spain. Theme-based instruction also frames our particular context of a language class in a school of engineering, insofar as the syllabus is subordinated to themes that are suitable for these engineering students' general educational curriculum. However, the instruction here is also highly conditioned by other significant factors, such as skills development and the use of ICT.

As presented in the literature (Gaffield-Vile 1996, Kasper 1997), theme-based language instruction has traditionally relied to a great extent on content aspects of the courses, in particular the topic, the organizing principles, the linguistic focus and the language learning objectives. Similarly, the corresponding methodology derives from highly conventional proposals mostly used today in other general language or language for specific purposes courses. In our view, the integration of language skills, their organization in modules, tasks or class projects in the past were very innovative, challenging and highly adequate proposals for different levels and contexts, but at this 
point they should not be seen as examples of "new" methodologies. In order to further adapt theme- or topic-based instruction to our current times and needs, language programmes must also be implemented, rather than merely described, in terms of general or more specific non-linguistic skills and abilities that the students will achieve together with the learning of the language. As a matter of fact, new programmes adapted to the higher education area highlight the fact that subjects are no longer designed in terms of content alone, but instead include other "competences" to be improved during the course. Thus, the specific course outcomes demonstrate the acquisition of such competences. As Tuning (2000) put it:

Competences can be distinguished in subject specific and generic ones. Although Tuning acknowledges to the full the importance of building-up and developing subject specific knowledge and skills as the basis for university degree programmes, it has highlighted the fact that time and attention should also be devoted to the development of generic competences or transferable skills. This last component is becoming more and more relevant for preparing students well for their future role in society in terms of employability and citizenship.

\section{II.3. Use of ICT}

An additional step towards the planning of new courses must include the integration of ICT. Over the last few years, the use of the Virtual Learning Environment (VLE) Moodle in the EUIT de Telecomunicación has allowed both materials and activities to be adapted to a virtual environment where students can work autonomously. Depending on the different subjects, this adaptation can take many forms. At the most basic level, it allows traditional materials, such as Word or PDF documents, links to web pages, and presentations in Power Point, to be organized in the corresponding space of the platform. However, it can also involve the exploitation of every resource offered by the virtual environment for continuous evaluation, such as synchronous and asynchronous student-to-student communication, student and instructor communication, and collaborative activities and tasks. The latter was the case with the subjects preceding "English for Professional and Academic Communication" in the former Technical degrees. The virtual environment, Moodle, had implications for the entire curriculum and was seen mainly as a means of promoting learner autonomy. B-learning was seen as a good opportunity to provide students with the necessary tools and enough material and guidance to work independently. 
The new course design presents optimal conditions for the use of the virtual learning environment Moodle. If, in the past, the platform was seen as an opportunity to help students to overcome the difficulties related to their varied proficiency levels and anxiety derived from communicating in a foreign language (Argüelles Álvarez 2011), these are not the main aims any more. Currently, the platform has been transformed into a meeting-point which favours not only course organization but also communication among the members of the group when performing individual or collaborative tasks and project work. With regard to the methodology adopted, blended learning implies a commitment to exploit both Moodle and classroom resources in a complementary way. A task-based approach (Nunan 1993) with an emphasis on communicative competence has been followed in order to effectively integrate all the resources offered by both the traditional classroom and the virtual environment. However, similarly to what has happened with task- or project-based methodologies, b-learning is no longer a “novelty”.

If we want to further integrate Information and Communication Technologies into our daily routine and work on capacities, here is a unique opportunity for students in the area of Telecommunications to apply most of the generic competences grouped in Tuning (2000) into three types: instrumental, interpersonal and systemic. The constructive model proposes an initial hypothesis that language is learnt when there is a real need for communication (Halliday 1975, 1978). This model can be established as the basis for a motivational orientation related to the non-linguistic aspect of the subject, where students must use the foreign language in order to fulfil the course assignments. These course assignments are in the form of Learning Objects, thus our students in the area of Telecommunications can actively participate in the development of LO, which can later be used autonomously or as part of different subjects.

An LO is "Any entity, digital or non-digital, that may be used for learning, education or training”; “Any digital resource that can be reused to support learning Web-based interactive chunks of e-learning designed to explain a stand-alone learning objective" or "A digitized entity which can be used, reused or referenced during technology supported learning" (Technology Glossary of Terms). Beginning in the year 2000 (Murphy 2004), with huge advances in technology on the part of organizations such as the Institute of Electrical and Electronics Engineers (IEEE), the concept of Learning Object became 
well-known. Pertaining to the teaching of languages, this fundamental technological aspect implies that modular and self-content material (i.e. LO) can be imported or exported from one platform to any other. Its reusability and its easy localization also imply the need for the collaboration of professionals from different fields. Furthermore, the researchers del Moral and Cernea (2005) pointed to the participation of students in the development of these materials as a means to convey new knowledge, a learning process also defended and applied in the past (Argüelles Álvarez 2005, 2006).

\section{ENGLISH FOR PROFESSIONAL AND ACADEMIC COMMUNICATION}

In our Centre, as is also the case in the rest of Spain, a particular level of proficiency in accordance with the CEFRL is required for students to complete their degree. In our case, students are also required to achieve a specific proficiency level to enrol in a specific subject. Students who enrol in EPAC are in the fourth year of their degree in Telecommunications Engineering, although by and large they have been at the University for longer. Some students will certify their B2 level in English by presenting an official certificate, while others will begin the EPAC course after passing two introductory subjects that prepare students with a B1 to reach the required level. In the latter case, and upon completion of the two preparation courses, students take an internal B2 accreditation test. The result is that students who enrol in EPAC do not demonstrate, as was the case in the past, a "mix-match" of proficiency levels. As opposed to the past, wherein there was considerable variation in terms of levels, in our current situation the affective factors derived from performance in the foreign language (Brown 1981, Gardner and Macintyre 1993) do not need to be considered to the same extent. The negative influence of such affective factors in proficiency development, especially when the students have to speak in front of others, seems to be much less in these homogeneous groups with an upper intermediate level of proficiency.

The course-wide strategy of EPAC is based on previous observation of groups enrolled in subjects of similar characteristics over the past ten years, as well as the study of their possible adaptation to the new contextual needs. In the framework of the external constraints described previously, the general approach that could best describe the course are a task- / project-based syllabus which includes a negotiated component along 
with the integration of technologies in order to establish a more interactive relationship among the students and between the whole group of learners and the instructor. One particular advantage of project work is that either language or skill problems can be dealt with when they arise. Another interesting aspect is that students can work on a topic of interest within their specific field of knowledge, such as reading and listening selectively in preparation for a final presentation. Connected with the aforementioned context, the approach allows a negotiated component to be adopted, although within an external syllabus, which provides the students with opportunities to further intervene in their own learning (based on Holec 1987, or Holme 1996). Thus, we are speaking here of the interaction of approaches and methodologies and their integration with ICT into a b-learning course.

\section{III.1. Programme}

The programme means a further step from the original course entitled Professional Communication, included in the former technical degree curriculum (two modules of English for Academic and Professional Purposes, the first focused on writing skills and the second on oral ones), which had undergone a previous revision process to adapt the language-based course to a content-based organization (Argüelles Álvarez 2011). This previous subject was then conceived as covering four parts or areas of content $-\mathrm{a}$ ) socializing, b) telephoning, c) job searching, and d) presentations. The first steps towards adaptation have been taken respecting these content modules, but the emphasis is on the last two, whereas "socializing" was crucial in the previous subject. Whilst "Professional Communication” was mainly thought of as being integratively-oriented, the new "English for Professional and Academic Communication" is more instrumentally-oriented. After the first semester (Autumn 2012-2013) teaching what was considered to be the pilot course to a group of fourteen students, results showed that B2 learners in this subject expected to learn the language for more utilitarian reasons rather than speaking for socializing, which had been a priority among their fellow students in the past. Either their higher level of proficiency or their previous experience learning English could explain this change: students have sufficient command of the English language to socialize in informal contexts or to survive when 
travelling, and some or most of them have had the opportunity to practise their English with native or foreign speakers either face-to-face or on-line.

\section{III.1.1. Course modules}

The course is programmed for 160 hours throughout 15 weeks. This implies two twohour seminars (in-class activities) a week and 5-6 hours of personal work on the part of the students out of class. There are 12 students enrolled in the second pilot group (Spring 2012-2013) ${ }^{1}$ after a first experience in the first semester. In the adapted programme, the first two modules, which include topics such as greetings, introductions, language learning and learning styles or talking on the phone and e-mail writing, are covered in $20-25 \%$ of this time. This part of the course is mainly devoted to re-programming or to adapting the programme to the needs and interests of the group. The first aim is to allow students to participate, thus giving them more responsibility in their learning process. For instance, students give their opinion regarding the use of materials during the course or the organization of individual sessions. A learning contract can eventually be included at this point to organize their work outside of class sessions. The second aim is to raise self-awareness by asking them to reflect on their own needs and those of the rest of the group. Listening or video activities where different international students analyse their strengths and weaknesses regarding their use of English as a foreign language can be used as a model for reflection. Furthermore, a questionnaire on the virtual environment Moodle or in a .pdf file, including specific questions which address the most common difficulties of non-native speakers in the different skills, can favour their personal needs analysis. This questionnaire will include a section with questions regarding the importance of English for a Telecommunications Engineer in order to allow the students to notice that there are specific needs derived from their future career activities. An open activity in the forum in Moodle can encourage the exchange of opinions about the importance of the different skills for an engineer. The final aim is to help students understand the importance of autonomous learning. Once their personal needs have been established, students realize that a

\footnotetext{
${ }^{1}$ Although the original course is programmed for 30 students per group, the actual enrolment in these first years is conditioned by two important factors: the first one is that the subject EPAC is taught in the $7^{\text {th }}$ semester of the new plans and few students have actually passed the previous courses; the second is that only a small number of students in the $7^{\text {th }}$ semester have certified a B2 level according to the CEFRL and thus cannot enrol in the subject.
} 
personal work schedule must be developed and followed in order to further attend to individual needs based on the activities completed in class (see Appendix 1 for an example of the content and methodology followed).

Reflection on autonomous learning is a crucial factor, as students will need to work independently for many hours. In addition, it establishes the basis in the traditional inclass sessions and in a collaborative way for organizing a "realistic" personal and group plan to take an active role during the course. Students discuss different issues regarding the tasks and content with the instructor and course assignments are negotiated. This negotiation is always understood within the limits of a pre-established general programme that has been published in the students' guide in advance. The length of time to be spent on the projects, usually ranging from two weeks to more than a month, is also negotiated. Moodle not only serves here as a means for the individual to communicate with the rest of the group but also as a meeting point where doubts or questions are answered and where suggestions concerning how to better deal with an activity, task or problem are received (Figure 1).

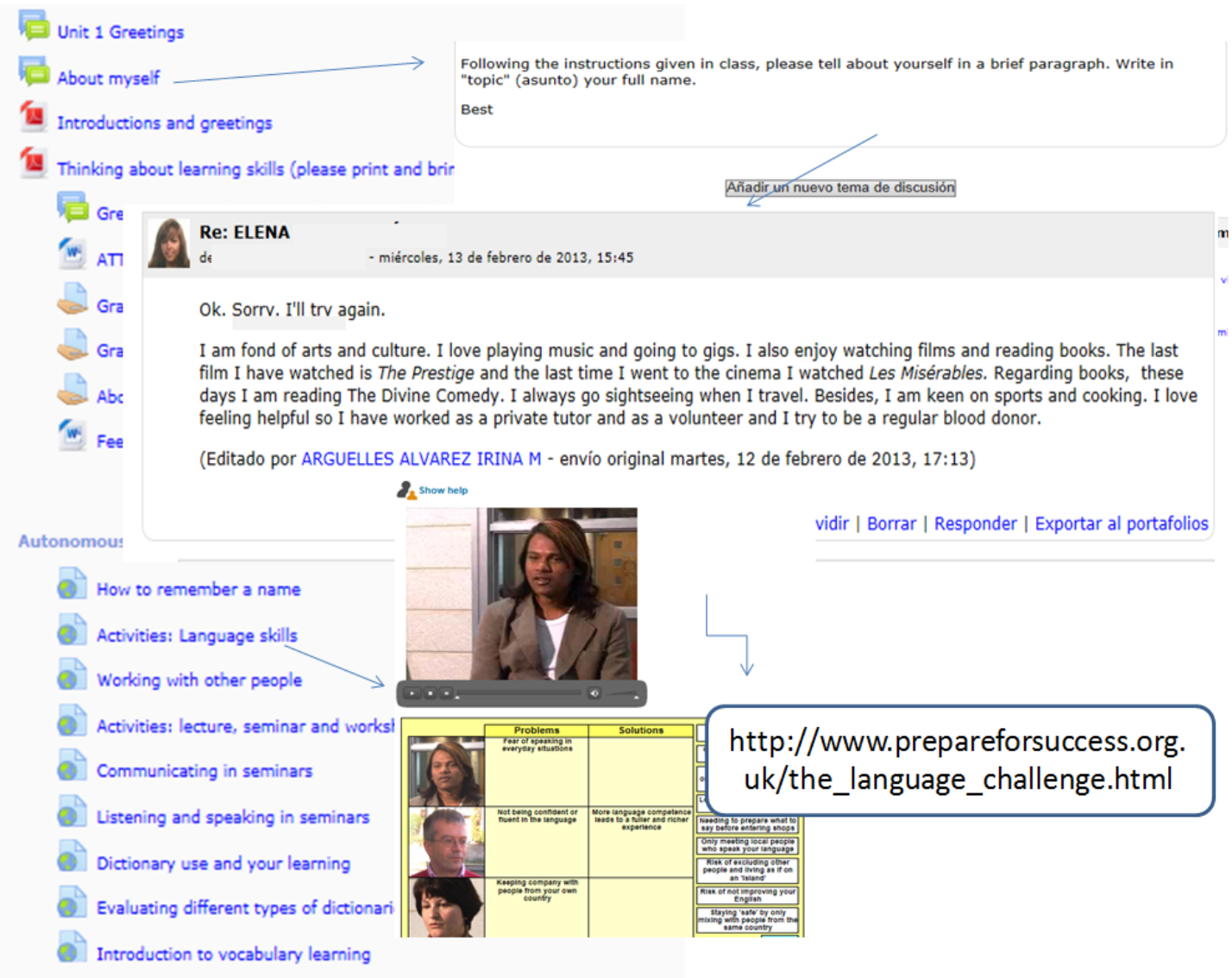

Figure 1. View of Module 1 in the VLE Moodle with examples of activities. 
The third and fourth modules take up the rest of the programmed time in the course, approximately $75-80 \%$. In this part of the course, the students have acquired the routine of individual and group work. Regarding the collaborative activities, most of them are carried out in informal groups rather than in more formal ones. These modules are a priori based on more conventional decisions affecting the syllabus design in terms of learning aims - knowledge of textual forms and vocabulary in the area of Telecommunications; comprehension of specialized discourse; analysis of text type and audience; synthesis of information from diverse sources etc. - and learning outcomes: to take notes in conferences, meetings or debates; to recognize and to use typical expressions in different situations; to use the bilingual and monolingual dictionary; to organize information; to write a text; to adapt speech at the level of formality required by the context; to recognize different types of academic and professional texts, etc. As stated previously, a more expository approach is adopted in this part of the course in order to meet these course aims and outcomes agreed upon in the Department.

The modules “Job interviews” and "Presentations” follow a lexical-functional approach, with task- or content-based instruction and integrated general skills for those specific contexts. We should not forget the importance of grammar even within a communicative approach, as according to Widdowson (1990: 98): “On the contrary, it involves recognition of its central mediating role in the use and learning of a language”. Brinton and Holten (2001) reported dissatisfaction on the part of the students enrolled in their content-based courses and called for more attention to grammar in response to their wishes and needs. Master (2000), on the other hand, suggested a more systematic treatment of grammar integrated within CBI using content as a point of departure for expanding the grammar explanation beyond the structure found in the materials and then linking back to the content.

Deciding on an approach to grammar instruction that fits CLIL is further complicated by the fact that students have differing opinions about the types of grammar instruction that they find helpful. However, the syllabus is adaptable enough to incorporate additional activities (as extra material or revision) both in the classroom and in the platform as they become useful in the learning process. It is worth emphasizing here the substantial amount of time and motivation needed to improve the instructors' own skills to adapt to this b-learning holistic approach, not to mention the difficult role of the 
teacher as a "facilitator", always ready to adapt to the situation, to think of a more productive way to solve different problems and willing to incorporate new activities in the traditional class or on the platform, and who thus requires the technical knowledge needed to do so.

\section{III.1.2. Course activities}

In the CBI classroom, most of the activity types corresponded in the past to what Mohan (1986) calls experiential approaches. Experiential activities include role-plays, workshops, simulations, demonstrations and interaction with native speakers. In the new subject we are adopting a more expository approach which, according to the same researcher, relies on activities such as lectures, reading of articles and other texts, student presentations and classroom discussions, where content may be anything that meets the needs of our engineering undergraduates. Both kinds of activities, traditionally employed in the CBI classroom, are presented here within a constructive learning model where knowledge is constructed based on personal experiences (Halliday 1975, 1978). In this context, the focus is the project that learners attempt to fulfil; the problem drives the learning, while the students learn domain content in order to solve the problem, rather than solving the problem as an application of learning. In addition, the results of the class project come out in the form of LO, which has emerged as a new way of thinking about learning content. Learning objects are small, reusable, self-contained units of learning, typically ranging from 2 minutes to 15 minutes, and can be taken independently. Learning objects include descriptive information, allowing it to be found easily by conducting a search. In addition, it can be aggregated in larger course structures, including most traditional ones (Chiappe et al. 2007).

\section{III.2. Project work}

As described in the introductory sections of this work, the activities and tasks in the traditional class are presented within a constructivist model of learning. Based on previous experiences both in Spain and abroad (García Famoso 2005, Wilkinson 2008), our educational approach to this model is a problem-based learning one (Hernández Encuentra and Sánchez Carbonell 2005), wherein the acquisition of disciplinary content 
is integrated by means of confrontation with "problems" of a technological nature. Learning is determined by prior knowledge as students are stimulated to seek new information to find solutions to "the problem". In broad terms there is only one: to create a Learning Object derived from the compulsory class tasks. On this occasion the class project is carried out by the whole group, as there are 12 students enrolled this semester. Therefore, the activity is strongly led by the instructor, which becomes an important factor to consider, as for good or for bad, the tutor's involvement might determine group functioning, interest and achievement.

\section{III.2.1. Students}

Although traditionally these groups of professional communication have been heterogeneous, in this second pilot semester the students are mostly enrolled in the speciality of Sound and Image. Nine students out of twelve are studying this speciality while the other three come from the speciality of Telematics.

\section{III.2.2. Class project}

In accordance with the students' background and interests, the class project is designed for them to develop activities related to their field of expertise. The final activity revolves around a job interview, the final product being a video showing typical questions and examples of desired answers at a job interview. In the module "Job searching”, among other activities, students read, listen to and watch videos, role-play and reflect on typical job interview questions and suitable answers (see Appendix 2 for an example of the content and methodology followed). In the fourth week of the course students are introduced to the general idea of the final class project. This final project will be the focus of the group activity for the rest of the course and therefore must be carefully selected, in such a way that it becomes challenging and engaging as well as clearly structured and well presented.

The final product on this occasion is a 10-minute video in English with subtitles exemplifying ten questions and answers typical of a job interview. The students are informed beforehand that the TV studio will be available with the support of staff from the Department and that the software to edit the video will be provided. The students are 
also informed that they will organize and develop the project plan, the instructor being regarded as part of the group, since she will provide advice concerning the use of language in the final draft of the script. Furthermore, in her role as a mediator between the group and the staff in the Department of Sound and Image, the instructor will attend to students' requests or further queries regarding the organization of the project. As agreed in advance, the video should be ready in about a month (four to five weeks).

Nonetheless, the class project is not limited to the development of a final product. The project will be completed by the end of the semester when the students in the group present the technologies, including the hardware or software used to produce the video. In addition, students are required to provide the technical details about the development of the activity, giving an opinion and reaching a final conclusion. During the last month of the course, the students are taught how to give presentations and how to write a proposal. As a final step, they will have to prepare the topic and give a presentation explaining every technical aspect influencing the class project activity. Examples of such topics could be the description of a TV studio and the advantages of working there, the illumination, or the features of the camera or cameras used. Other suitable themes include their choice concerning the software used to edit or to subtitle the job interview. The presentations are therefore fully integrated into the class project as a final task.

\section{III.2.3. Assessment}

In this framework, the evaluation of the students' activity cannot be limited to the assessment of a final product. In fact, the mark given for the final product should represent only a minimum percentage of the final mark. The assessment of the class project must necessarily consider a number of aspects to evaluate and, although the experience to be evaluated is "new", the assessment process and the weight attached to such different aspects are well grounded on previous experience.

In the preceding semester's pilot experience, the assessment of the course was based on two intermediate formal tests, where students were asked to complete activities mostly based on aspects of vocabulary and language use, but which also included writing and listening activities. These tests represented $40 \%$ of the course final mark. Although not integrated as part of a class project, there was a final task presentation activity in the 
module "Presentations" that has been kept together with the 200 to 250-word proposal, which counted as $30 \%$ of the students' final mark. The remaining $30 \%$ was assessed through other activities completed during the course, both in and outside the classroom, involving the support of the VLE Moodle.

The assessment of the class project stems from this broad distribution of the breakdown of the evaluation after revising the time devoted to the different activities throughout the course. As we stated in previous sections, the adapted programme covers the first two modules including greetings, introductions, language learning and learning styles, as well as talking on the phone and e-mail writing in approximately $20-25 \%$ of the total course time. These modules are strongly based on language use and functional phrases which can be easily tested through a more conventional pen-and-paper procedure on the first test. Other aims of the first two modules (i.e. reflection on self-awareness or autonomous learning) are not evaluated here. While the third and fourth modules take up $75-80 \%$ of the course time, and it is precisely during this part of the course that the class project is developed, it is thus reasonable to base most of the evaluation on the process and the results obtained here. Therefore, the class project, including the students' work in the traditional classroom and in the VLE, the fulfilment of intermediate tasks, the final product as well as a final proposal and a presentation will represent $75 \%$ of the final mark for the course.

\section{RESULTS}

The students show a great deal of interest when presented with the project. They have not had any previous experience in the TV studio, or this has been limited to a short practical carried out in groups, and thus they consider this chance a good opportunity to have a new experience. Typical job interview questions and their answers are prepared collaboratively based on the ideas presented in class. Guided by the instructor, students write the project layout on a wiki in the VLE Moodle, including the motivation of the project, the objectives, and describing the intermediate tasks and the final product, analysing the resources they will need and proposing a work schedule. The wiki allows the whole group to participate and registers their work. The students meet twice in the TV studio and answer one question each in front of the camera (a total of 12 questions 
and answers). Furthermore, all of them answer two extra questions: "Can you tell me briefly about yourself?" and "What is the last book you have read or the last film you have seen?” These are the opening and closing questions that link the project with the first part of the course, which is when these topics are covered.

During the first part of the course, and also in order to answer the job interview questions, students have previously reflected upon their competences and abilities, as well as the importance of these factors in their role as engineers. When preparing their speech, students revise the professional content of the EPAC course, paying attention to their use of the language, key words, pace, intonation and body language, among others. Out of class time, but within the hours students must spend on the subject, they edit the videos and give them subtitles. At this stage students are involved in contents of their speciality, developing their research autonomously either in groups or individually, while dealing with instructional information on how to carry out these technical tasks. They share information and distribute the work load mostly through the VLE, as they need to be in permanent contact and have their decisions registered. The final product is a 13-minute video in English with subtitles exemplifying ten questions and answers typical of a job interview (Figure 2). Students must consider aspects of the language concerning accuracy. When writing the subtitles, they will detect some unavoidable language mistakes and while reviewing, they will have the chance to evaluate their own performance and achievements. 
We want our employees to have experience,

but you don't mention it on your CV so, why

do you think you are the best candidate for this job?
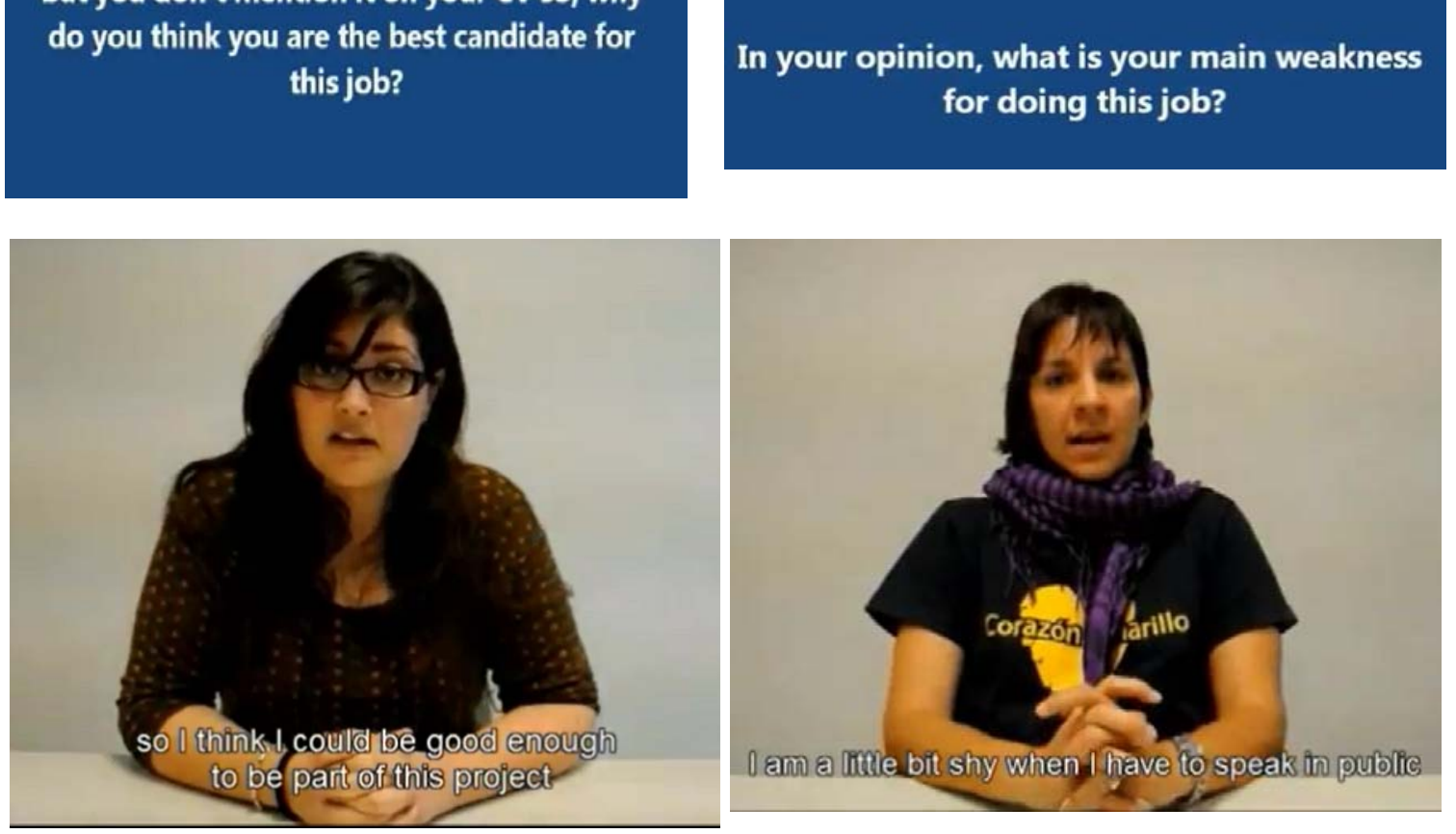

Figure 2. View of the final video with subtitles (with permission of the students).

At the end of the course, students hand in their work, evaluate and explain their part in the development of the final task and present one of the technical aspects related to the experience. At this stage of the course, they will reflect on their attitude towards the task and demonstrate knowledge of a particular technical aspect and the related vocabulary. To avoid spending too much time on the activity and in order to make the final presentations more dynamic, challenging and interesting, students use the Pecha Kucha ${ }^{2}$ technique for their final presentations, in which accuracy, fluency and creativity are key elements (Figure 3).

\footnotetext{
${ }^{2}$ Pecha Kucha is a presentation methodology in which 20 slides are shown for 20 seconds each http://www.pechakucha.org
} 


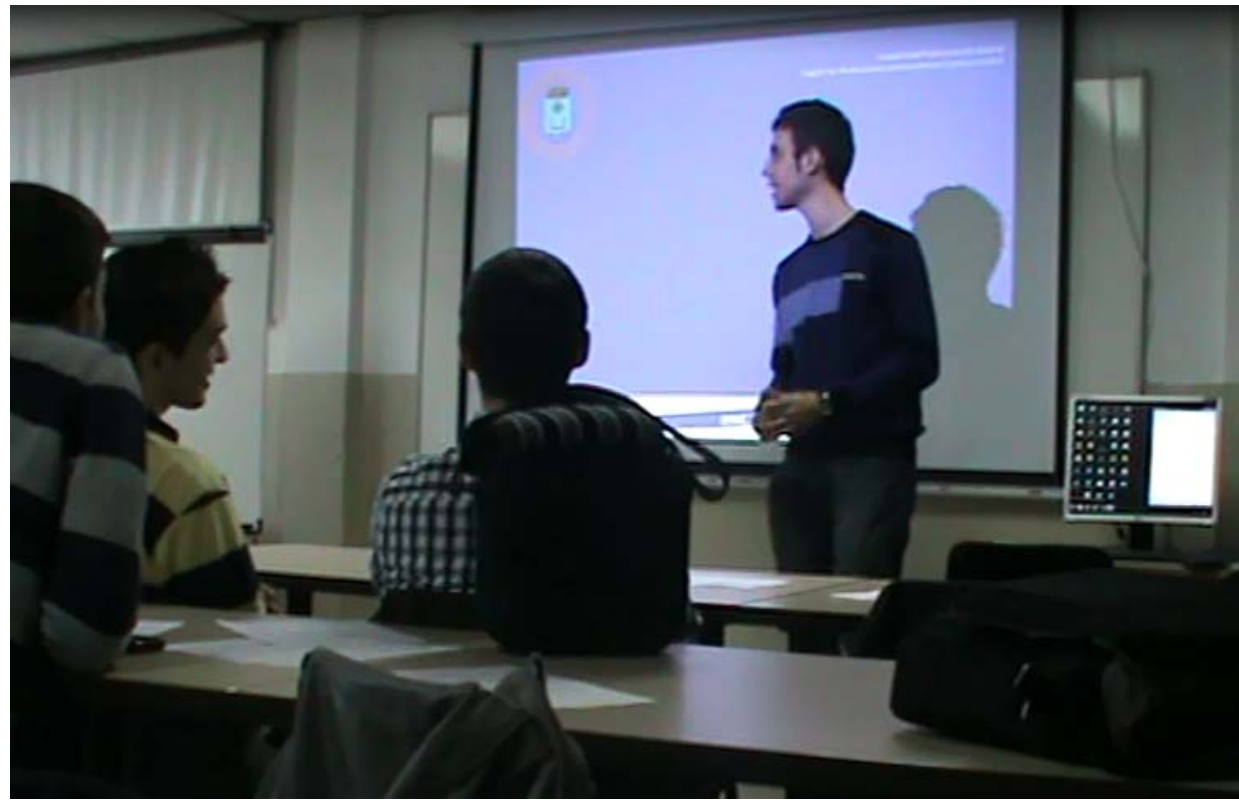

Figure 3. View of the Pecha Kucha session (with permission of the students).

Coming back to the competences of the Bologna process, the students report having put into practice most of the generic competences: instrumental, interpersonal and systemic competences, included in the Tuning (2000) list during the EPAC course. On a questionnaire where all the original Tuning competences were listed, 10 students in the group (two of them were not present) were asked to give a weight of 5 (much practice), 3 (some practice), 1 (less practice) or 0 (no practice) to the competences during the course, the results thus obtained being those summarized in Table 1, where the number (1-7) represents the skill weight as given by the students.

Table 1. Top 10 generic competences most practised during the EPAC course as perceived by the students.

\begin{tabular}{|l|l|l|}
\hline Competences & Much practice & Some practice \\
\hline Instrumental & $\begin{array}{l}\text { 1.Oral and written } \\
\text { communication in English } \\
\text { (Weight: 100\%) }\end{array}$ & $\begin{array}{l}\text { 6. Ability to communicate with } \\
\text { experts in other fields }\end{array}$ \\
\hline Interpersonal & $\begin{array}{l}\text { 3. Teamwork } \\
\text { 4. Interpersonal skills }\end{array}$ & $\begin{array}{l}\text { 2. Concern for quality } \\
\text { 3. Capacity for generating new } \\
\text { ideas (creativity) } \\
\text { 5. Will to succeed } \\
\text { 5. Ability to work autonomously }\end{array}$ \\
\hline
\end{tabular}


Systemic competences are highly recognized by students as having been practised during the course, together with other much more evident interpersonal skills, such as teamwork. Let us call the readers' attention to the second in order of importance, “concern for quality”, which in fact might be understood as one of the most difficult to programme in a course. Thus, those abilities must be assessed together with oral and written communication in English.

Assessment should be viewed holistically in a language and content integrated course, where students must demonstrate a range of capacities. In order to obtain this holistic view of the results, two skill categories have been distinguished apart from the most obvious instrumental one: a) teamwork and other interpersonal skills, and b) systemic competences. Both of these areas can be assessed through different alternative measures such as: skills checklists, anecdotal records and teacher's observation, student selfevaluation or performance-based tasks. Many of the alternative assessment measures proposed have been described previously (cf. Pierce and O’Malley 1992, or Short 1991) and therefore these will not be explained here. We will briefly conclude that these methods have the advantage of being quick, capturing the learning process vividly and offering opportunities for reflection as well as encouraging students' participation. The main disadvantage is probably that most of these methods are yes-no measures, whereby it is hard to show the students' progress, and thus they will not generally satisfy requirements of "accountability”. As Short (1993: 635) put it: “The key is to select the type or types of assessment carefully and to focus consistently on the objective”.

Communication competences, which play a key role in the EPAC course, have been separated from the rest in order to be assessed by means of other more extensively used procedures within CLIL courses, such as essays, e-mail or proposal writing, oral reports and presentations as well as personal interviews. On the whole, class project assessment results in positive back-wash (Alderson and Hamp-Lyons 1996) as assessment objectives fit the skills outlined in the course objectives and practised throughout the semester. Nevertheless, some standardized tests and pen-and-paper tests must continue to be used, although these may no longer be viewed as the only satisfactory means of measuring students’ achievement. 
Let us now come back to the concept of Learning Object (LO), which was presented in the introductory sections to this work in relation to the outcomes of the course. Modular and self-content material has been used in the EPAC course in Moodle, but can also be seen as a result in our context. The final product obtained from the class project will also be packaged in a format that allows its reusability and easy localization and will be part of the materials used in the EPAC classroom in further semesters within the EPAC course in the module "Job Searching" within the section entitled "Job Interviews". Materials renewal and update will also result from the students' development of LO.

As mentioned previously, the instructor has been closely involved with the 12 students throughout this experience, which on the one hand might have influenced satisfactory group functioning, but on the other resulted in an excessive workload for the teacher. When the number of students in the group reaches 30, the course organization and assessment must necessarily be thoroughly studied and detailed in advance, as any aspect of the course which has not been previously considered will inevitably result in a great workload for the teacher. The organization of the VLE in weeks instead of the option of modules selected here could be more practical and benefit not only the organization of the class project but also the continuous assessment process. Furthermore, although the class project is presented after a month as an assignment that is independent of the first part of the course, there is a clear transition and a solid connection between the first activities performed over the first weeks and the project itself. Both parts could be explicitly linked in order to organize the whole course within a long-term final project.

\section{CONCLUSIONS}

The proposal presented herein has been the product of years of adapting to new situations, which have resulted in a gradual awareness, study and revision of the different aspects involved in the learning process in our EPAC courses. The course project undertaken during the spring semester of the present year has exemplified the suggested holistic approach geared towards Content and Language Integrated Learning, where, in addition to communication skills and IT literacy, students get practice in a range of other general skills. Furthermore, the holistic approach aims to develop the 
learners' autonomy, which is seen here as a capacity to take control of learning (Benson 2001, Sinclair 2000). The project design has included the description of general and specific aims also referring to skills and capacities, a final project to be developed and the necessary intermediate tasks scheduled for a set time. The methodology applied to the project assessment has also been reviewed, as well as the necessary resources to complete it.

Analysis and reflection on the specific aims achieved suggest that this offer is adequate in the framework of Telecommunication studies at tertiary levels, whilst providing a satisfactory example of integration of language, professional and academic content and specialized content together with other skills and capacities, including the use of technologies and autonomous learning. Nevertheless, it is worth emphasizing here the need for an urgent revision of the teacher's role as a facilitator in order to evaluate and regulate the cost-effectiveness of this new role demanded from lecturers within the European Area of Higher Education. Our feeling is the same as Bocanegra-Valle's (2008: 227) when she concludes from her CLIL experience that “[...] it was very demanding and time-consuming”. Projects such as the one presented herein must be carefully modulated and transformed into more realistic and less energy-consuming proposals to be able to carry them out as a regular routine.

\section{ACKNOWLEDGEMENTS}

I wish to thank Professor Ceo-DiFrancesco (Ph.D., Xavier University, Cincinnati, Ohio) for her revision and encouraging comments on the final draft of this paper.

\section{REFERENCES}

Alderson, J.C. and Hamp-Lyons, L. 1996. "TOEFL preparation courses: A study of washback”. Language Testing 13, 280-297.

Argüelles Álvarez, I. 2005. “Adaptación de materiales y TIC para el fomento del aprendizaje autónomo”. RESLA 17/18, 19-33. 
Argüelles Álvarez, I. 2006. “Algunas reflexiones sobre la participación de LO alumnos en la adaptación de materiales para el aprendizaje autónomo en IPA”. Mélanges CRAPEL 28, 177-190.

Argüelles Álvarez, I. 2011. "New ICT literacies and holistic approaches for the effective learning of languages in tertiary education”. Odisea 12, 53-76.

Argüelles I., Sendra J., Millán M., Blanco J., Herradón R. and Herington R. 2011. “TIC y aprendizaje integrado de contenidos técnicos y lengua inglesa en la EUIT de Telecomunicación UPM”. In Maruenda-Bataller S. and B. Clavel-Arroitia (Eds.) Multiple Voices in Academic and Professional Discourse: Current Issues in Specialised Language Research, Teaching and New Technologies. Newcastle upon Tyne, UK: Cambridge Scholars Publishing, 428-441.

Benson, P. 2001. Teaching and Researching Autonomy in Language Learning. London: Longman.

Bocanegra-Valle, A. 2008. "Learning to learn in ESP: Fostering lifelong learning in European higher education under Bologna requirements”. In Fortanet-Gómez I. and C. Räisänen (Eds.) ESP in European Higher Education: Integrating Language and Content. Amsterdam: John Benjamins, 213-232.

Brinton, D.M. and Holten, C.A. 2001. "Does the emperor have no clothes? A reexamination of grammar in content-based instruction”. In Flowerdew J. and M. Peacock (Eds.) Research Perspectives on English for Academic Purposes. Cambridge: Cambridge University Press, 239-251.

Brown, H.D. 1981. “Affective factors in second language learning”. In Alatis J.E. (Ed.) The Second Language Classroom: Directions for the 1980's. Oxford: Oxford University Press, 113-129.

Chiappe, A., Segovia Y. and Rincón Y. 2007. “Toward an instructional design model based on learning objects”. Educational Technology Research and Development 55 (6), 671-681.

Dafouz, E. and Guerrini, M.C. (Eds.) 2009. CLIL across Educational Levels: Experiences from Primary, Secondary and Tertiary Contexts. Madrid/London: Santillana Educación / Richmond Publishing. 
Del Moral, M.E. and Cernea, D.A. 2005. "Diseñando objetos de Aprendizaje como facilitadores de la construcción del conocimiento”. In Proceedings of Simposio Pluridisciplinar sobre Diseño, Evaluación y Descripción de Contenidos Educativos Reutilizables (SPDECE), Universitat Oberta de Catalunya, Barcelona. 9 May $2013<\underline{\text { http://www.uoc.edu/symposia/spdece05/pdf/ID16.pdf }>}$

Ellis, R. 2003. Task-based Language Learning and Teaching. Oxford: University Press.

Fernández Fontecha, A. 2001. "Una selección bibliográfica sobre el método AICLE”. Contextos Educativos 4, 217-239.

Gaffield-Vile, N. 1996. "Content-based second language instruction at the tertiary level”. ELT Journal 50 (2), 108-114.

García Famoso, M. 2005 “Problem-based learning: A case study in computer science”. In Méndez-Vilas, A., B. González-Pereira, J. Mesa González, J.A. Mesa González (Eds.) Recent Research Developments in Learning Technologies. Badajoz, Spain: FORMATEX, 817-821.

Gardner, R.C. 1985. Social Psychology and Second Language Learning: The Role of Attitudes and Motivation. London: Edward Arnold.

Gardner, R.C. and MacIntyre, P.D. 1993. “A student's contributions to secondlanguage learning. Part II: Affective variables”. Language Teaching 26, 1-11.

Halliday, M.A.K. 1975. Learning How to Mean. London: Edward Arnold.

Halliday, M.A.K. 1978. Language as Social Semiotic: The Social Interpretation of Language and Meaning. London: Edward Arnold.

Hernández-Encuentra, E. and Sánchez-Carbonell, J. 2005. “The Bologna process and life-long education: Problem-based learning”. Higher Education in Europe 30 (1), 81-88.

Holec, H. 1987. “The learner as manager: Managing learning or managing to learn?” In Wenden, A. and J. Rubin (Eds.) Learner Strategies in Language Learning. London: Prentice Hall, 145-156.

Holme, R. 1996. “Negotiating needs and course content”. In Holme, R. ESP Ideas. London: Longman, 6-15. 
Kasper, L. F. 1997. "The impact of content-based instructional programs on the academic progress of ESL students”. English for Specific Purposes 16 (4), 309320.

Master, P. 2000. “Grammar in content-based instruction”. In Kasper, L.F. (Ed.) Content-based College ESL Instruction. Mahwah, NJ: Lawrence Erlbaum, 93106.

Mohan, B.A. 1986 Language and Content. Reading, MA: Addison-Wesley Publishing Company.

Murphy, E. 2004. "Moving from theory to practice in the design of web-based learning using a learning object approach”. E-Journal of Instructional Science and Technology 7 (1), 1-17.

Nunan, D. 1993. “Task-based syllabus design”. In Crookes, G. and S. Gass (Eds.) Task in a Pedagogical Context: Integrating Theory and Practice. Clevedon, England: Multilingual Matters, 55-68.

Pierce, L.V. and O’Malley, J.M. 1992. Performance and Portfolio Assessment for Language Minority Students. Washington DC: National Clearinghouse for Bilingual Education.

Schumman, J.H. 1986. "Research on the acculturation model for second language acquisition”. Journal of Multilingual and Multicultural Development 7 (5), 379392.

Sercu, L. 2004. "The introduction of English-medium instruction in universities. A comparison of Flemish lecturers' and students’ language skills, perceptions and attitudes”. In Wilkinson, R. (Ed.) Integrating Content and Language. Meeting the Challenge of a Multilingual Education. Maastrich: Maastrich University, 547555.

Short, D.J. 1991. How to Integrate Language and Content Instruction: A Training Manual. Washington DC: Center for Applied Linguistics.

Short, D.J. 1993. “Assessing Integrated Language and Content Instruction”. TESOL Quarterly 27 (4), 627-656. 
Sinclair, B. 2000. “Learner autonomy: The next phase?” In Sinclair B., I. McGrath and T. Lamb (Eds.) Learner Autonomy, Instructor Autonomy: Future Directions. London: Longman, 4-14.

Skehan, P. 1996. “A framework for the implementation of task-based instruction”. Applied Linguistics 17 (1), 38-62.

Tuning Educational Structures in Europe 27 October 2012 <http://www.unideusto.org/tuningeu/>

Unterberger, B. and Wilhelmer, N. 2011. "English-medium education in Economics and Business studies. Capturing the status quo at Austrian Universities”. International Journal of Applied Linguistics 161, 90-110.

Widdowson, H.G. 1990. Aspects of Language Teaching. Oxford: Oxford University Press.

Wilkinson, R. 2008. "Locating the ESP space in problem-based learning: Englishmedium degree programmes from a post-Bologna perspective”. In FortanetGómez I. and C. Räisänen (Eds.) ESP in European Higher Education: Integrating Language and Content. Amsterdam: John Benjamins, 55-74.

Received: 30 May 2013

Accepted: 18 August 2013

Cite this article as:

Argüelles Álvarez, I. 2013. "A holistic experience in the integrated learning of specialized English and content in engineering degrees”, Language Value 5 (1), 48-75. Jaume I University ePress: Castelló, Spain. http://www.e-revistes.uji.es/languagevalue. DOI: http://dx.doi.org/10.6035/LanguageV.2012.5.4

ISSN 1989-7103

Articles are copyrighted by their respective authors 
APPENDIX 1

EXAMPLE OF CONTENT AND METHODOLOGY

Session 1: Introductions, greetings and learning needs

( 2 hours class +2 hours homework)

\begin{tabular}{|c|c|c|}
\hline Warmer & $\begin{array}{l}5-10 \\
\min \end{array}$ & $\begin{array}{l}\text { Students greet one another using correct formulae and } \\
\text { body language }\end{array}$ \\
\hline $\begin{array}{l}\text { Brief } \\
\text { presentation of } \\
\text { the course }\end{array}$ & $\begin{array}{l}10-15 \\
\min .\end{array}$ & $\begin{array}{l}\text { Students should have read the guide, so the presentation } \\
\text { can be based either on specific questions about the } \\
\text { course or on any other possible questions they may have } \\
\text { Activity: in groups of five, students are asked to share } \\
\text { two things connected with the course they already know } \\
\text { and to prepare two questions. After 5-7 minutes results } \\
\text { are shared and questions regarding the subject are } \\
\text { answered by the instructor. Debate. }\end{array}$ \\
\hline \multirow[t]{2}{*}{$\begin{array}{l}\text { Paper copies } \\
\text { "Language } \\
\text { skills" }\end{array}$} & $\begin{array}{l}20-30 \\
\min .\end{array}$ & $\begin{array}{l}\text { Students prepare their answers to questions about their } \\
\text { learning styles. Students prepare their answers in groups } \\
\text { of three (10-15 min.) Whole group debates the answers } \\
\text { to the questions ( } 10-15 \text { min.) }\end{array}$ \\
\hline & $50 \mathrm{~min}$. & \\
\hline $\begin{array}{l}\text { Video } \\
\text { "Language } \\
\text { skills" }\end{array}$ & $\begin{array}{l}20-25 \\
\min .\end{array}$ & $\begin{array}{l}\text { Activities including revision of expressions used in the } \\
\text { video, grammar or vocabulary. }\end{array}$ \\
\hline Needs analysis & $\begin{array}{l}20-25 \\
\min .\end{array}$ & $\begin{array}{l}\text { In new groups of three: personal needs and group needs; } \\
\text { then, whole group debate. }\end{array}$ \\
\hline \multirow[t]{2}{*}{ Wrap up } & $\begin{array}{l}5-10 \\
\min \end{array}$ & $\begin{array}{l}\text { A learning challenge! Students think for one minute and } \\
\text { say aloud the most important problem they have as } \\
\text { students of English and how they expect to solve it. }\end{array}$ \\
\hline & $50 \mathrm{~min}$. & \\
\hline
\end{tabular}

Homework: Students complete the activities in Moodle. Content of the session, linguistic aspects and grammar or vocabulary are reviewed in questionnaires or openended activities. 


\section{APPENDIX 2}

\section{EXAMPLE OF CONTENT AND METHODOLOGY}

Session 12: Preparing for a job interview III

( 2 hours class +3 hours homework)

\begin{tabular}{|c|c|c|}
\hline Warmer & $5 \mathrm{~min}$. & $\begin{array}{l}\text { Greetings, revision of phrases in a formal situation, body } \\
\text { language. }\end{array}$ \\
\hline $\begin{array}{l}\text { Video "DOs } \\
\text { and DONTs } \\
\text { at a job } \\
\text { interview }\end{array}$ & $15-25$ min. & $\begin{array}{l}\text { Whole group watch the video in } \\
\text { http://www.youtube.com/watch?feature=player_embedde } \\
d \& v=S 1 \text { wcmfPOBV8 ( } 10 \text { min.). Students take notes and } \\
\text { exchange their information in pairs ( } 5 \text { min.). After } \\
\text { watching the video again, whole group share information } \\
\text { (10 min.). }\end{array}$ \\
\hline \multirow[t]{2}{*}{$\begin{array}{l}\text { Could you } \\
\text { tell me } \\
\text { about } \\
\text { yourself? }\end{array}$} & $15-20$ min. & $\begin{array}{l}\text { Students prepare a brief answer to this question in pairs; } \\
\text { students exchange pairs and ask and answer the question } \\
\text { (10-15 min.); whole group revise content, grammar and } \\
\text { vocabulary (10 min.). }\end{array}$ \\
\hline & 50 min. & \\
\hline $\begin{array}{l}\text { Lesson “Job } \\
\text { interview } \\
\text { techniques" }\end{array}$ & $10-15$ min. & $\begin{array}{l}\text { In pairs, students read the questions and answers } \\
\text { proposed and complete information gap activities (5-10 } \\
\text { min.). Comments and questions (whole group } 5 \text { min.). }\end{array}$ \\
\hline $\begin{array}{l}\text { Reading } \\
\text { texts: } \\
\text { "Getting } \\
\text { ready for a } \\
\text { job } \\
\text { interview" }\end{array}$ & 25-30 min. & $\begin{array}{l}\text { Pair-work. Either using laptops or printed on paper } \\
\text { students read texts where advice is given about how to } \\
\text { prepare for a job interview (see for example results in } \\
\text { Google for "getting ready for a job interview"). Students } \\
\text { take notes and revise if there is any new information to } \\
\text { add to that studied during the sessions or through the } \\
\text { activities in Moodle (15 min.). Whole class feedback (10- } \\
15 \text { min.). }\end{array}$ \\
\hline \multirow[t]{2}{*}{ Wrap up } & 5-10 min. & $\begin{array}{l}\text { Select the three most difficult questions to answer from } \\
\text { the ones studied during the module. Share your list. }\end{array}$ \\
\hline & 50 min. & \\
\hline
\end{tabular}

Homework: Students complete the activities in Moodle. Content of the session, linguistic aspects and grammar or vocabulary are revised in questionnaires or openended activities. 